\title{
APPLICATION OF GIS AND GROUNDWATER MODELLING TECHNIQUES TO IDENTIFY THE PERCHED AQUIFERS TO DEMARKATE WATER LOGGING CONDITIONS IN PARTS OF MEHSANA
}

\author{
D . Rawal ${ }^{\mathrm{a}}$, A.Vyas ${ }^{\mathrm{a}}$, S.S.Rao ${ }^{\mathrm{a}}$. \\ a CEPT University, Ahmedabad, India - rawalnet@yahoo.com,anjanavyas@yahoo.com, ssrao1742@gmail.com
}

Commission VIII, WG VIII/4

KEY WORDS: Ground Water, Hydrological Cycle, Geology, Rainfall. Piezometer.

\begin{abstract}
:
Groundwater is very important component of the hydrological cycle. It is an important source of water for drinking, domestic, industrial and agricultural uses. It plays a key role in meeting the water needs of various users sectors in India. Ground water resource is contributed by two major sources - rainfall and the other seepage from irrigation of the crops. A man-made effort through artificial recharge for water conservation structures adds to the ground water. The ground water behaviour in Indian subcontinent is highly complicated due to the occurrence of diversified geological formations with considerable lithological and chronological variations, complex tectonic framework, climatological dissimilarities and various hydro-chemical conditions. Assessment of ground water resources of an area requires proper identification and mapping of geological structures, geomorphic features along with sound information regarding slope, drainage, lithology, soil as well as thickness of the weathered zones.
\end{abstract}

This study is to understand the ground water scenario in the water logged areas of Dharoi command while the surrounding areas showing continuous decline of water levels. The area falls in the command area of Dhorai dam and is in Mehsana District of Gujarat State. A part of northern command of Dharoi Command area falls in hard rock areas while the lower and southern portion fall in alluvial areas in the Dharoi Command (RBC) area in Mahsana Mehsana District of the Gujarat State.

The study highlights the application of GIS in establishing the basic parameters of soil, land use and the distribution of water logging over a period of time and the groundwater modelling identifies the groundwater regime of the area and estimates the total recharge to the area due to surface water irrigation and rainfall and suggests suitable method to control water logging in the area.

\section{INTRODUCTION}

Assessment of ground water resources of an area requires proper identification and mapping of geological structures, geomorphic features along with sound information regarding slope, drainage, lithology, soil as well as thickness of the weathered zones. Amongst the latest available technologies, the remote sensing technique along with Geographic Information System (GIS) has acquired the supreme position over the conventional methods in studying the hydrogeology due to its synoptic view, repetitive coverage, and high ratio of benefit to cost and availability of data in different wavelength ranges of the electromagnetic spectrum. Through digital image processing of the remotely sensed satellite images, the controlling features of ground water can be identified accurately and thus the terrain can be classified properly in terms of ground water potentiality and prosperity. Geographic Information System (GIS) has been found to be one of the most powerful techniques in assessing the suitability of land based on the spatial variability of hydro geological parameters. GIS offers many tools to extract the information about the ground water prospect of an area by integrating information regarding geologic structures, geomorphology, soil, lithology, drainage, land use, vegetation etc.

Gujarat is the seventh largest state of India, situating in the Western part of the country is largely an arid state for most of its part. In the mountainous hard rock terrain of Aravalli, ground water is the only source of water in the northern part of the Gujarat. A part of Northern command of Dharoi command area falls in hard rock areas while the lower and southern portion fall in alluvial areas. Due to the combination of hard rock areas and the perched water table conditions occurring due to the occurrence of clay at very shallow depths in parts of the Dharoi Command (RBC) in Mahesana District of the Gujarat state particularly in Kheralu, Vadnagar, Visnagar and Unjha Talukas have water logging conditions. The objective of this study is to understand the hydrogeology of the terrain and its influence in ground water and then to develop an appropriate ground water modelling using Visual Modflow to delineate the water logging areas and suggest suitable methods to recharge the lower aquifer and estimate the approximate amount of water that can be recharged in the area.

\section{OBJECTIVE}

- To delineate the aerial extent of the perched aquifer and study the geohydrological characteristics of perched and deeper aquifer system.

- To quantify the ground water withdrawal and recharge input potential of layered aquifer system and assess its adverse effects due to shallow water levels.

- To develop a mathematical model of Part of Vadnagar, Visnagar and Kheralu and Unjhataluka of Mahesana district of North Gujarat Region representing perched aquifer system (approximately $605 \mathrm{Sq} . \mathrm{Kms}$ ).

\section{STUDY AREA}

Dharoi Canal Command Area of Gujarat State encompasses seven talukas of Mahesana and Sabarkantha District. The study area comprises of656.28 sq.km. The area is mainly drained by Rupen River along with its tributaries. The area falls in the command area of Dhorai dam and falls in Mehsana District of Gujarat State. The area covers Vadnagar ,Kheralu, Visnagar 
and Unjha Talukas. The location of the study area is shown in the map below:

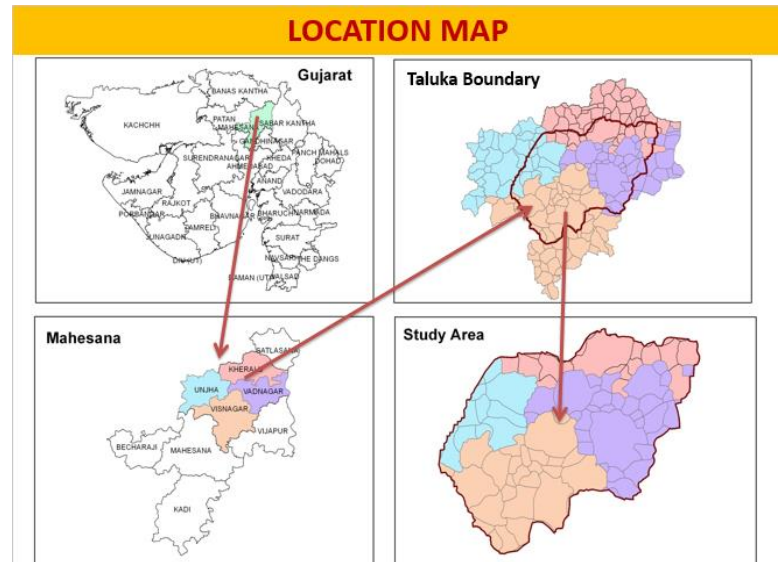

Figure 1 Study Area

\subsection{Physiography and Drainage}

The study area has a diverse landscape. It is characterized by hilly upland in the northeast, followed by piedmont zone with shallow alluvium and residual hills/inselbergs, and rolling to gently sloping vast Alluvial-Eolian plain. The elevation in the study ranges from less than 95 meters in the southwestern part, and 194 meters above mean sea level (AMSL) in the northeastern part. The master slope is towards southwest. The higher elevations in the study are attained by hills in the northwest.

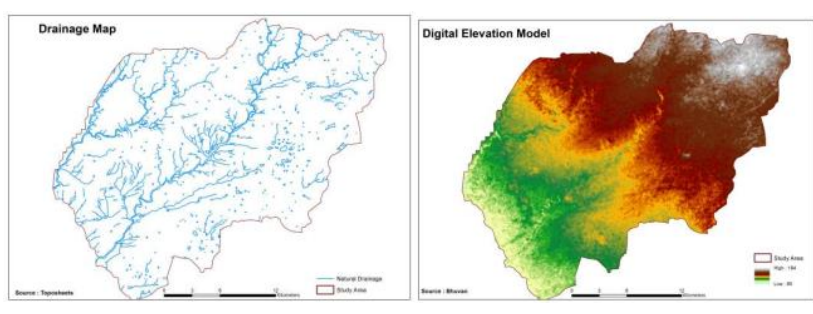

Figure 3 Elevation and Natural Drainages

\subsection{Climate:}

The district has semi-arid climate. Extreme temperatures, erratic rainfall and high evaporation are the characteristic features of this type of climate. The climate of the district, like other parts of North Gujarat, is dominated by hot summer, cold winter, meagre rainfall and a general dryness except during the short monsoon period. The year may be divided into four seasons. The period from March to mid-June is the hot summer season followed by south-west monsoon which lasts till September. October and November are the post-monsoon months when the temperatures rise again. The winter season starts from December and ends in February.

\subsubsection{Rainfall:}

The average rainfall in the area is about $660.42 \mathrm{~mm}$. The standard deviation is about 331.57 indicating that the coefficient of variation is almost $50 \%$. It shows that the rainfall is highly irregular and cannot be depended upon. It is mainly concentrated during June to September months. The annual variation of rainfall is shown below
3.2.2 Temperature: After mid-March there is a rapid rise in temperature and May is the hottest month with mean daily maximum temperature of $41.7^{\circ} \mathrm{C}$ and mean daily minimum

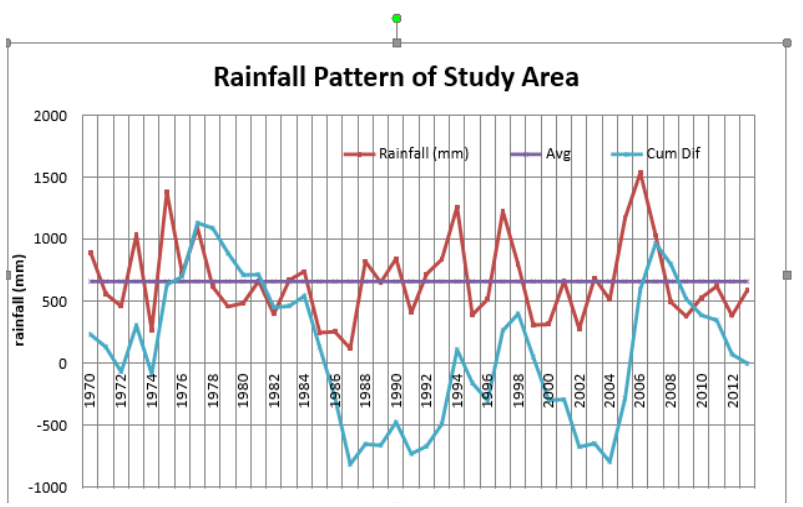

Figure 2 Rainfall Pattern

temperature of $25.3^{\circ} \mathrm{C}$. In hot season strong dust laden scorching winds blow on many days and the weather becomes uncomfortable. On individual days, the day temperature may go above $45^{\circ} \mathrm{C}$

After October, both night and day temperatures decrease. January is the coldest month with mean daily maximum and minimum temperature of $28.4^{\circ} \mathrm{C}$ and $10.7^{\circ} \mathrm{C}$ respectively. During the winter season the district is affected by cold waves associated with western disturbances. On such occasions the minimum temperature may drop down to 1 or 2 degrees below freezing point. The highest and lowest temperatures recorded at Deesa are $50^{\circ} \mathrm{C}\left(15\right.$ th May 1912) and $2.2^{\circ} \mathrm{C}$ (15th Jan 1935).

3.2.3 Humidity: During the monsoon period the humidity is between $60-80 \%$. On an average, humidity is low during the year. The driest period of the year occur during winter and summer seasons when relative humidity in the afternoon is less than $30 \%$.

3.2.4 Surface Water Resources: The study area is deficient in respect of surface water resources. There are no perennial rivers flowing through the study area and thus the water resources are dependent mainly on the surface run-off and river flows during monsoon period. In order to harness surface water resources, major and medium irrigation projects were planned and executed. The existing irrigation schemes and command area of Dharoi command canal in the study are shown in the map.

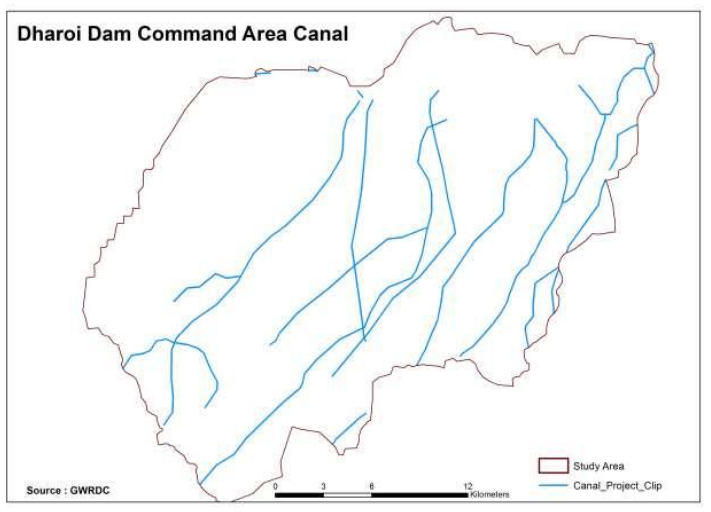

Figure 4 Canals of the Dam Command Area 
3.2.5 Land Utilization Pattern: The total area reported for land use purpose in the study area was 656.26 Sq. KM. The area is demarcated from the satellite image of year 1998 and 2008. The maps and table of the land use classification are follows:

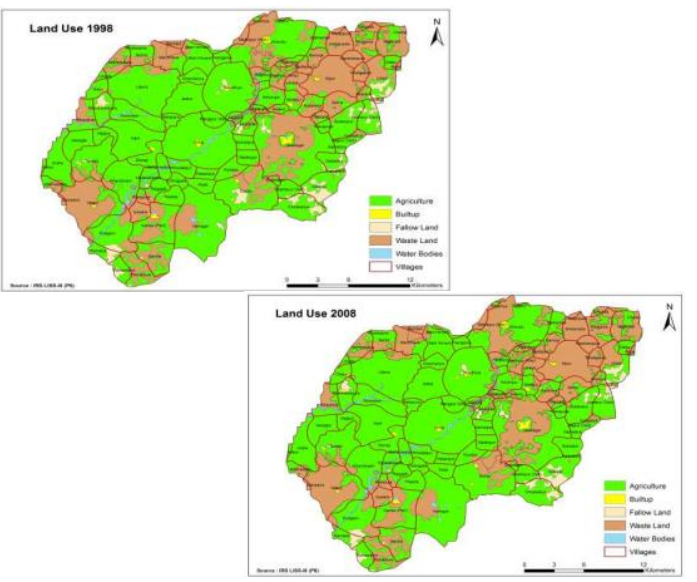

Figure 5 : Land USE Map

Table 1 Landuse

\begin{tabular}{|l|l|l|l|l|l|l|}
\hline Land Use & $\begin{array}{l}\text { Area } \\
\text { in } \\
\text { Sq. } \\
\text { Km } \\
1998\end{array}$ & $\begin{array}{l}\text { Area } \\
\text { in } \\
\text { Sq. } \\
\text { Km } \\
2008\end{array}$ & $\begin{array}{l}\text { Change } \\
\text { in } \\
\text { the Land } \\
\text { Use in } \\
\text { Sq. Km }\end{array}$ & $\begin{array}{l}\text { Land } \\
\text { Use } \\
\text { in } \\
1998\end{array}$ & $\begin{array}{l}\text { Land } \\
\text { Use in } \\
\% 2008\end{array}$ & $\begin{array}{l}\text { Chang } \\
\text { e in } \\
\text { Land } \\
\text { USE } \\
\text { in \% }\end{array}$ \\
\hline Built-up & 4.37 & 4.45 & 0.09 & 0.67 & 0.68 & 0.01 \\
\hline Agriculture & 429.65 & 431.77 & 2.12 & 65.47 & 65.79 & 0.32 \\
\hline Fallow Land & 20.99 & 17.11 & -3.89 & 3.20 & 2.61 & -0.59 \\
\hline Waste Land & 195.25 & 196.93 & 1.67 & 29.75 & 30.01 & 0.26 \\
\hline Water Bodies & 6.02 & 6.02 & 0.00 & 0.92 & 0.92 & 0.00 \\
\hline Total Area & 656.28 & 656.28 & 0.00 & 100.00 & 100.00 & 0.00 \\
\hline
\end{tabular}

Above table represents the category-wise land use derived from the respective years' satellite imagery. The study area is 656.28 sq.km. Comparisons made between Land Use which is carried out from the Satellite images of year 1998 and 2008. Area under agriculture is decreasing, the built up area also increase. Agriculture in this region depends mainly on rainfall. The fallow land has marginally decreased. Differences are seen in the above table that Waste lands are increasing because of water logging. With increase in the Salinity, land is converted in to Waste land. The IRS data LISS-III images of $23.5 \mathrm{~m}$ resolution were used to derive land use maps of the year 1998 and 2008.

3.2.6 Agriculture: Study Area is primarily an agricultural land with about $80 \%$ of the total reported area under cultivation and more than $65 \%$ of its working population engaged in agriculture and agro related activities. Months of sowing and harvesting of major crops in this region Wheat is the major crop grows between the months of October and March. The second important crop is Jowar, which is grown between August and December months. The cash crops, groundnut and cotton are also grown in the study region.

\subsection{Hydrogeology:}

3.3.1 Geology and sub-surface Geology: The total area falls in quaternary alluvial deposits of more than $400 \mathrm{~m}$ depth with more than 4 major aquifer formations. The aquifers are mainly alluvial formations except in the North East portion of the area where basement rock is exposed at about 35- 50 to $\mathrm{m}$ depth. The geology of Dharoi canal command area is shown below. It shows that the aquifers in the North are hard rock, valley fills in the middle and the older alluvium in the extreme south.

Generally the groundwater moves and follows the topography in unconfined aquifers those move from North East to South West in the study area.. In northeast and in west part basement is observed at shallow depth. The clay layers are thick and dominant in the area. Sand layers are thin in lenses form. The panel diagram obtained from the litho logs of the tube well of the area is shown below:

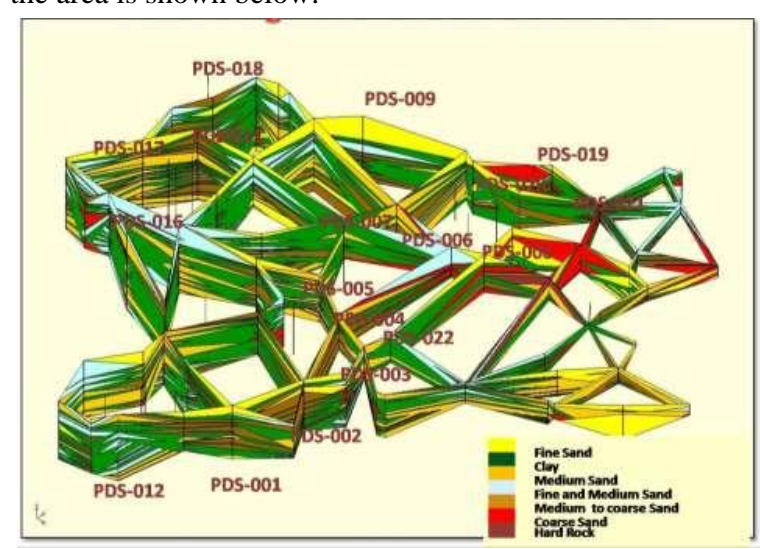

Figure 6 Geological Structure

The actual layers observed are more than 20 that are not amenable for modelling. Hence those are compressed into 6 layers. The first 5 layers are indicated as it is. However, the other clay and sand layers are compressed based on the percentage of clay available in the area.

3.4 Ground Water in Fissured Formations (Hard Rocks) : Primarily the thickness and extent of weathering zones, and size and interconnection of fissures and joints, which provide secondary porosity, govern occurrence and movement of ground water in the hard rocks. The high hills, in general, act as run off zone because of steep gradients and impervious nature of formations. Only in low lying terrain and intermountain valleys, ground water occurs in shallow weathered and fractured zones under water table to semi-confined conditions. In such areas the blown sand occurs as thin capping.

These formations, in general, do not form good repository of ground water. The depth of wells ranges from 8 to $18.5 \mathrm{~m}$ below ground water level and depth to water level in open wells varies from 5 to $14 \mathrm{~m}$ below ground water level. The water table is shallow near streams and topographically low areas. Yield of wells ranges from 30 to $120 \mathrm{~m}^{3} /$ day with an average of $75 \mathrm{~m} 3 /$ day. Open wells generally sustain intermittent pumping during summer season.

\subsubsection{Ground Water In alluvial formations:}

Primarily the thickness and extent of weathering zones, and size and interconnection of fissures and joints, which provide secondary porosity, govern occurrence and movement of ground water in the hard rocks. The high hills, in general, act as run off zone because of steep gradients and impervious nature 
of formations. Only in low lying terrain and intermountain valleys, ground water occurs in shallow weathered and fractured zones under water table to semi-confined conditions. In such areas the blown sand occurs as thin capping.

These formations, in general, do not form good repository of ground water. The depth of wells ranges from 8 to $18.5 \mathrm{~m}$ below ground water level and depth to water level in open wells varies from 5 to $14 \mathrm{~m}$ below ground water level. The water table is shallow near streams and topographically low areas. Yield of wells ranges from 30 to $120 \mathrm{~m}^{3} /$ day with an average of $75 \mathrm{~m} 3 /$ day. Open wells generally sustain intermittent pumping during summer season.

\subsubsection{Ground Water In alluvial formations:}

Major part of the study area is underlain by post-Miocene alluvium and older sedimentary formations. These sediments mainly consist of fine to coarse-grained sand, gravel, silt, clay, clay stones, siltstones and grit. Thickness of alluvium gradually increases from piedmont zone in the northeast towards west and southwest. Maximum thickness of alluvium in the district is estimated to be about $550-600 \mathrm{~m}$ in the central part.

Ground water occurs both under phreatic and confined conditions within sedimentary formations. The occurrence and movement of ground water is mainly controlled by intergranular pore spaces. Two major aquifer units identified.

Ground water is extensively developed by dug, dug-cum-bored and tube wells in areas underlain by alluvium. Depth of dug and dug-cum-bore wells ranges from $5 \mathrm{~m}$ to $65 \mathrm{~m}$ below ground water level whereas depth to water level, in general, varies from 10 to $20 \mathrm{~m}$ below ground water level. Deeper water table, between 20 and $32 \mathrm{~m}$ below ground water level, however, is observed in the central part, south of Saraswati River, and in the eastern part. In such areas, the dug section of the wells is generally dry and ground water is extracted directly from the bores and/or tube wells that generally tap deeper aquifers. Depth to water level in phreatic aquifer is shallow, less than $10 \mathrm{~m}$, in command areas of Dharoi covering parts of Patan and Kheralu, Visnagar, Mahesanatalukas. Also in entire southwestern part, where ground water is saline, water levels are shallow. In such areas dug wells are rare and/or located in or vicinity of ponds. Ground water development using dug wells and/or shallow bore wells in phreatic aquifer is limited because of salinity in major part, deep water levels and limited saturated water column and/or major yields in some areas also to some extent presence of high yielding deep aquifers. Such areas are confined and localized in parts of Kheralu. The yield of wells is generally low to moderate and ranges from 200 to $800 \mathrm{~m} 3 /$ day for 3 to 5 m drawdown.

The tube wells are the main groundwater withdrawal structures in the district and range in depth from $60 \mathrm{~m}$ to $350 \mathrm{~m}$. Shallow tube wells $(<100 \mathrm{~m})$ are restricted to the alluvial area in the northeast, mainly in parts of Kheralu and Vijapurtalukas. In the central, southwestern and southern parts, deep tube wells tap one or more aquifers. The depth to piezometric surface of deep confined aquifers ranges from near surface in the southwestern part to more than $120 \mathrm{~m} \mathrm{bgl}$ in the central part. The discharges of tube wells vary from 20 to $60 \mathrm{lps}$ for $8 \mathrm{~m}$ to $13 \mathrm{~m}$ of drawdown. The average yield of a $250 \mathrm{~m}$ deep tube well is around $20 \mathrm{lps}$. The transmissivity of deeper aquifer varies from 300 to more than $1200 \mathrm{~m} 2 /$ day.
A very rapid pace of ground water development from deep aquifers over the years with practically no control in the use pattern combined with prolonged years of deficit rainfall particularly in eighties has resulted in tremendous lowering of the piezometric surface. This has resulted in well failures, lowering of discharge and increased depth of tube wells over the years.

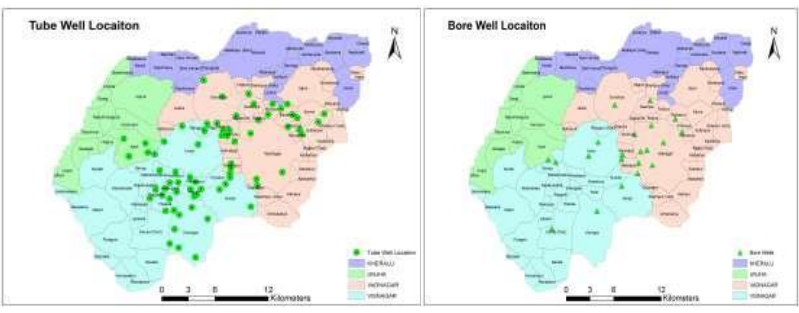

Figure 7 Well Locations

water logged area of Dharoi RBC, 22 numbers of open wells are fixed in year 2009.The locations of the wells are presented in above figure these structures are monitored monthly for water level measurement and water sampling.

3.4.3 Behaviour of Water Levels in Unconfined AquiferA1: The thematic map showing the land use patterns, drainage, soils etc are prepared in GIS environment, the thematic layers on dynamic data in terms of water level and quality variation over the space and time, the information collected is validated as base level information and using this layer important assessment on changes due to recharge activities envisaged under study. The spatial and temporal analysis has been considered for the dynamic data..

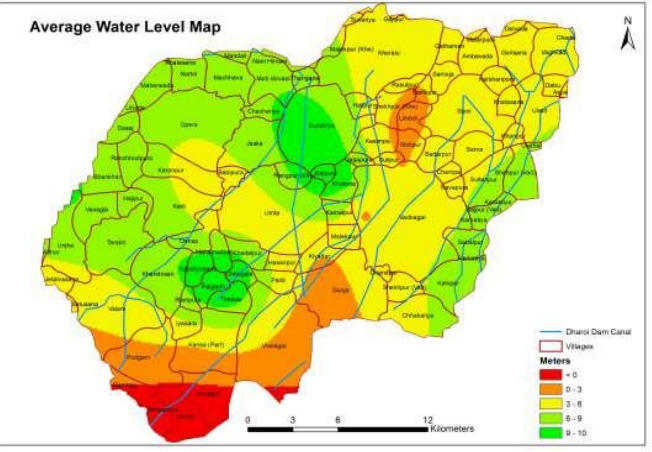

Figure 8 Average Water Level

3.4.4 Ground Water Quality : Periodic water levels in unconfined conditions are measured in the area in about 22 PDS wells since 2009 and the average ground water levels in the area is about $4.17 \mathrm{~m} \mathrm{(bgl)}$ while maximum is about $17.7 \mathrm{~m}$ (bgl). In some of the areas, the water levels are reaching almost ground level causing water logging conditions. The piezometric levels in confined conditions in the area vary from $40 \mathrm{~m} \mathrm{bgl}$ to $120 \mathrm{~m} \mathrm{bgl} \mathrm{A}$ few hydrographs are shown below.

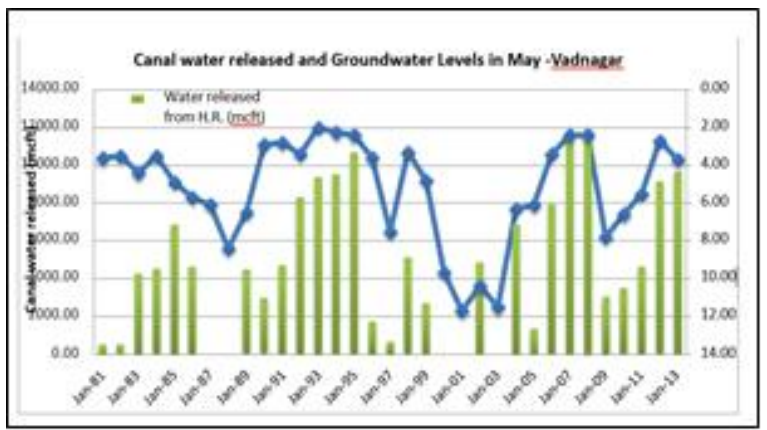

Figure 9 Canal Water Released and Ground Water Level 
The total dissolved solids in the prevailing groundwater vary from less than $1000 \mathrm{ppm}$ to more than $4500 \mathrm{ppm}$ in the water logged areas depending on the level of water logging. The maximum concentration $4500 \mathrm{ppm}$ is found in the southern western part of the study area during the monsoon, Rabi seasons and in a summer it is concentration in only center part of the study area and villages of Visnagar and Vadnagar Talukas. Groundwater quality maps for different seasons have been prepared to study the variation in seasons and years.

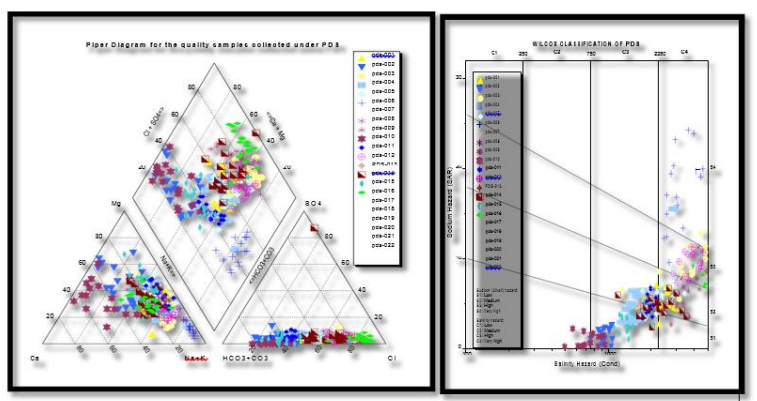

Figure 5 : Pepper Diagram for Water Quality

The quality of water has been analyzed using Wilcox classification to study the usability water for irrigation.The data of PDS wells in the study area are plotted using Aquachem software. The results indicate that $2 / 3 \mathrm{rd}$ of samples fall in $\mathrm{c} 3-\mathrm{c} 4$ and $\mathrm{s} 2$ to $\mathrm{s} 3$ zones indicating the groundwater is highly prone to salinity and sodium hazard. This appears mainly to water logging in the area and not suitable for irrigation

3.5 Groundwater Modelling : Modelling is an attempt to replicate the behaviour of natural groundwater or hydrologic system by defining the essential features of the system in some controlled physical or mathematical manner. Modelling plays an extremely important role in the management of hydrologic and groundwater system.

The reliability of any groundwater model depends on a proper simulation of the groundwater situation in the basin. This depends on proper calibration, for which the availability of the data on the geometry and hydraulic characteristics of the aquifer and data on water levels and the water balance are indispensable.

\subsubsection{The Conceptual Model: References from Other Literature:}

- The study area has been demarked based on the canal distribution, water logged area and drainage pattern of the area.

- It is observed that even though, the area is having more than 20 aquifer zones and has a depth of more than 300 to $400 \mathrm{~m}$, as the problem is of water logging, it is proposed to study the shallow aquifers in detail, to estimate the scope of artificial recharge to deeper aquifers, in the beginning and subsequently more depths if required. The aquifer sequence proposed study is shown.

- The surface contours are drawn based on DEM

- The initial water levels are collected from the dug wells /DCBs.

- The unconfined groundwater flows mainly from NE to SW of the area.
- The North boundary in general is constant boundary

- A part of North East is considered as General Head boundary as they are in likelihood of recharge from Northern side.

- A part of South West is Constant head boundary

- The remaining area outside the study area is considered as no flow boundary.

- The inside of the study area is considered as Active area.

3.5.2 Ground-Water Flow Equation: The partialdifferential equation of ground-water flow is given as under:

( McDonald and Harbaugh,1988).

$$
\frac{\partial}{\partial x}\left(K_{x x} \frac{\partial h}{\partial x}\right)+\frac{\partial}{\partial y}\left(K_{y y} \frac{\partial h}{\partial y}\right)+\frac{\partial}{\partial z}\left(K_{z z} \frac{\partial h}{\partial z}\right)+W=S_{s} \frac{\partial h}{\partial t}
$$

Where,

$\mathrm{Kxx}$, Kyy , and Kzz are values of hydraulic conductivity along the $\mathrm{x}, \mathrm{y}$, and $\mathrm{z}$ coordinate axes, which are assumed to be parallel to the major axes of hydraulic conductivity $(\mathrm{L} / \mathrm{T}) ; \mathrm{h}$ is the potentiometric head (L);

$\mathrm{W}$ is a volumetric flux per unit volume representing sources and/or sinks of water, with $\mathrm{W}<0.0$ for flow out of the groundwater system, and $\mathrm{W}>0.0$ for flow in (T-1);SS is the specific storage of the porous material ( $\mathrm{L}-1)$; and $\mathrm{t}$ is time (T).Even though, the groundwater equations have been developed considering homogeneous aquifers, in general, they do not occur in real life situations. The conductivity values vary considerably in all the directions as well as the Storability values also vary considerably. In normal modelling designs, $\mathrm{kx}$ and ky values are taken as same unless otherwise specifically obtained and observed in pumping test data and the vertical permeability data is considered about 10 times less than the horizontal permeability and calibrated subsequently to check these values.

The basic idea of the finite difference method is that the model area is subdivided into a number of sub-areas or polygons. Two families of straight parallel lines make the simplest type of polygon networks, to the $\mathrm{x}$ and $\mathrm{y}$ direction, respectively, which together form a mesh of rectangles as shown below.

The value of the $\mathrm{H}$ at nodal point $(\mathrm{i}, \mathrm{j})$ of the mesh is the average of values of nodal points of $(i-1, j ; I, j-1 ; i+1, j ; I, J+1)$. This value is obtained by no of iterations as specified by the model builder or as per the requirement of the model.

3.5.3 Grid design: The entire study area has been divided into uniform grid, a number of layers with uniform thickness created. At the time of translating conceptual model to the numerical model, the properties will be assigned to the appropriate grid cells to represent hydrological structure. Grid cells above the topmost hydrological layer (and below the bottommost layer) are set as inactive. This grid is useful for transport where it is desirable to have fine vertical discretization. For this study we have 78 columns $(39 \mathrm{kms})$ and 66 rows $(33 \mathrm{kms})$ with an average grid size of $500 \mathrm{~m}$. The Model Study area is shown below.

\subsubsection{The base and top of the aquifer:}

The base of the aquifer has been deduced mainly from bore whole logs. The base of the aquifer for the present study is identified as (-)213 $\mathrm{m}$ below sea level and top of the aquifer is about $210 \mathrm{~m}$ above mean sea level totaling about $423 \mathrm{~m}$. there are more than 20 layers within $423 \mathrm{~m}$ thickness of the aquifers. 
However, as the study is restricted to the top few layers to study the effect of water logging and also to see whether the recharge from upper unconfined aquifer to lower confined aquifers, the total thickness has been clubbed to only 6 layers. The first 5 layers are kept as per the actual occurrence and the remaining all the layers are clubbed as one aquifer (6th layer).

\subsubsection{Boundary conditions:}

The boundary conditions are very important to identify the groundwater movement, the availability of water resources and any predictions thereof.

Broadly there are as under:

1. Constant head boundary conditions

2. General Head boundary conditions

3. Recharge/ River / Drain boundaries / Wall

4. No flow boundaries

5. Active elements

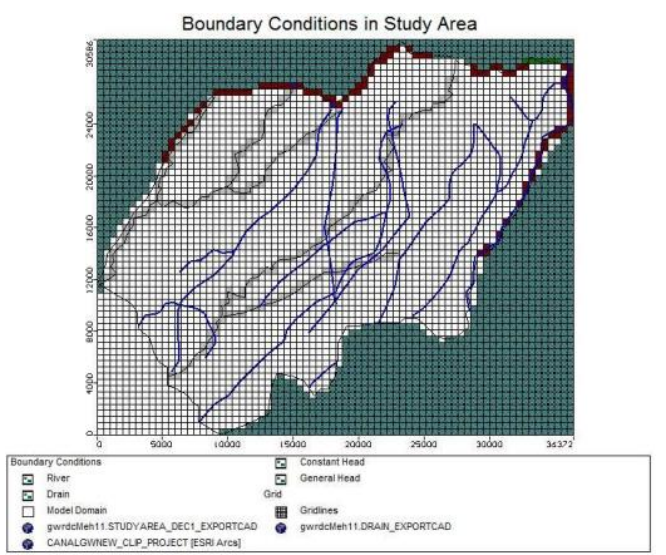

\section{Figure 11 Boundary Condition}

3.5.2 Model Input data: The model has been designed for steady state and unsteady state groundwater flow. The following inputs for elevations for different aquifers were used in the development of model. The aquifer parameter has been estimated based on the pumping tests conducted on the wells. Different type of the data like elevation of the Aquifer, Water Level and pumping data is included in the model.

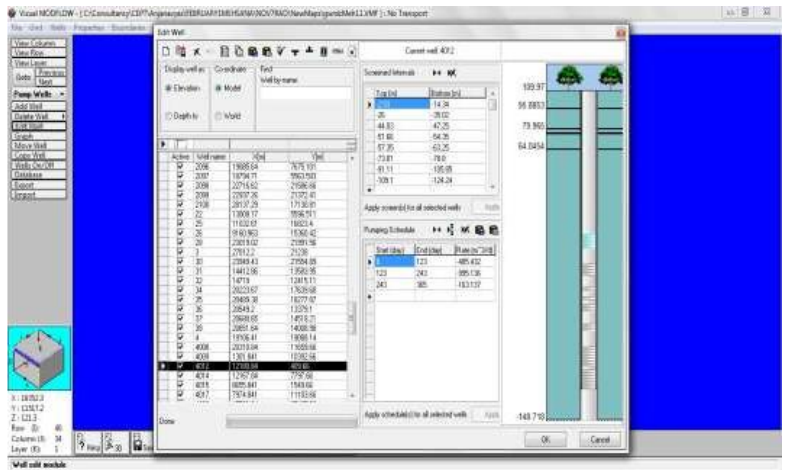

Figure 12 Input in the Model

The Model has been setup in Non Steady State condition for 365 days running period with monthly recharge values starting from July 1 and different pumping rates during Kharif, Rabi and Summer.
3.5.1 Behaviour of water table contours: The actual initial water table contours and estimated from the model are compared in the beginning of the year to see whether the model is working correctly. If they match reasonably, it can be safely assumed that the results would be acceptable. It is seen that the estimated and actual initial water levels are compared very well.

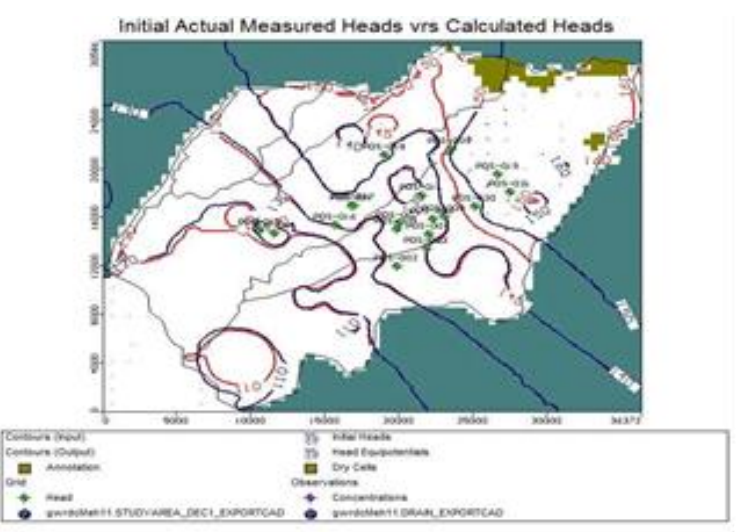

Figure 13 Water Behaviour Contour

3.6 Surface contours vs. Water: Water logging occurs where ever the surface contours and water table contours intersect. The depth to water table map shows that there are going to be water logging conditions in the South west and central part of the area.

The water table contour map along with surface contours is shown below to see whether any water logging occurs and subsequently to delineate the same. The water table contour map along with surface contours is shown below.
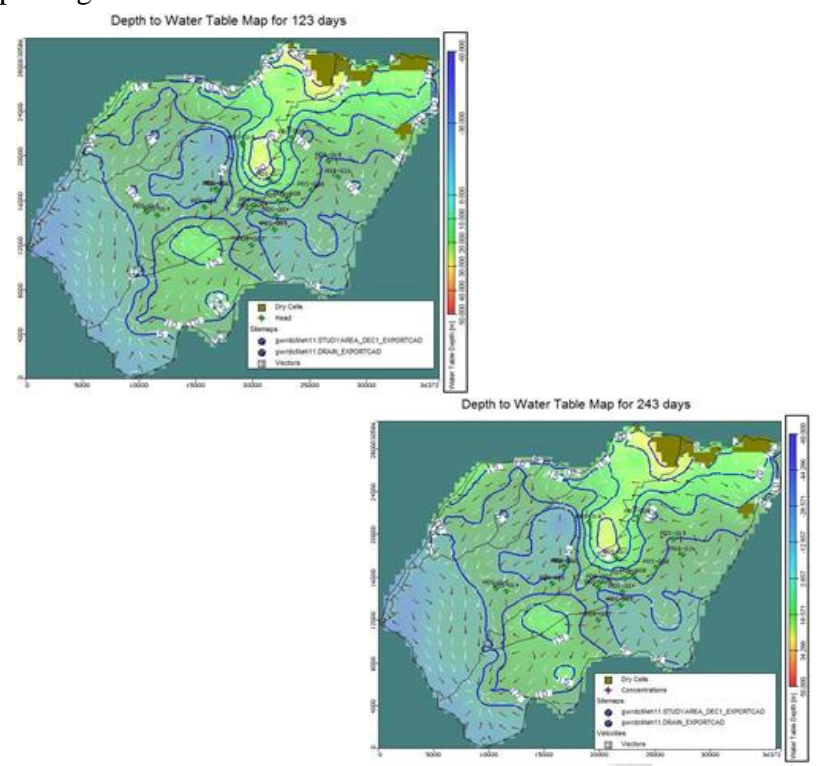

Depth to Wert Table Map for 365 days

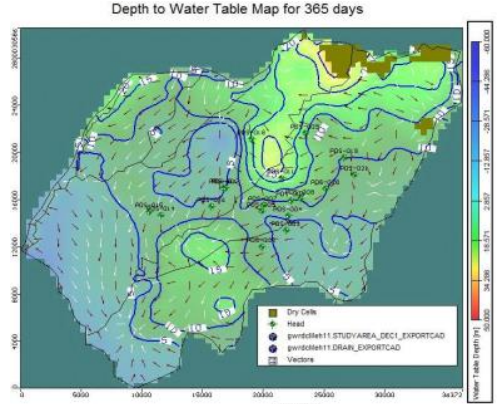




\begin{tabular}{|c|l|l|r|r|r|}
\hline well & $\mathrm{E}$ & $\mathrm{N}$ & $\mathrm{kx}$ & $\mathrm{ky}$ & $\mathrm{kv}$ \\
\hline 1 & 241914.90 & 2623085.0 & 3.29 & 3.2 & 0.329 \\
\hline 2 & 246140.90 & 2631321.0 & 7.05 & 7.0 & 0.705 \\
\hline 3 & 255176.50 & 2634933.0 & 11.88 & 11.8 & 1.188 \\
\hline 4 & 261210.00 & 2636051.0 & 24.7 & 24.7 & 2.47 \\
\hline 5 & 249066.90 & 2629497.0 & 9.58 & 9.5 & 0.958 \\
\hline 6 & 251090.90 & 2628576.0 & 23.5 & 23. & 2.35 \\
\hline 7 & 254832.00 & 2626628.0 & 7.24 & 7.2 & 0.724 \\
\hline 8 & 250438.20 & 2632133.0 & 9.58 & 9.5 & 0.958 \\
\hline 9 & 247681.60 & 2626086.0 & 4.12 & 4.1 & 0.412 \\
\hline 10 & 251807.30 & 2634658.0 & 7.49 & 7.4 & 0.749 \\
\hline 11 & 250864.20 & 2627250.0 & 1.69 & 1.6 & 0.169 \\
\hline 12 & 264076.10 & 2636779.0 & 6.97 & 6.9 & 0.697 \\
\hline 13 & 251630.70 & 2624356.0 & 4.12 & 4.1 & 0.412 \\
\hline
\end{tabular}

\section{Table 2 Well Location and Conductivity}

The equipotential lines for different aquifers for 365 days are given below. For the first unconfined aquifer, the equipotential lines as well as water table contours are drawn to see whether there is any difference between equipotential lines and water table conditions. Broadly they match except in the South Western part of the area.

In the confined conditions, the equipotential lines are similar as no separate initial water levels for different aquifers have been used.

\section{RESULTS OF THE MODEL:}

The user designates the sub-regions by specifying zone numbers. A separate budget is computed for each zone. The budget for a zone includes a component of flow between each adjacent zone. The zone budget for the whole year (365 days) indicates $1773300 \mathrm{~m}^{\wedge} 3 /$ day of water is coming into the area mainly from storage, constant head, recharge while the same amount is going out of the system from Storage, constant head, wells and through drains. The input and output should normally be equal when the water balance is studies. The contribution of different Zones (aquifers) to the unconfined aquifer is as under:

Table 3 Zone wise and Time wise calcualtion of Water loggin

\begin{tabular}{|l|c|l|r|l|}
\hline Inflow & $\mathrm{m}^{\wedge} 3 /$ day & Outflow & $\mathrm{m}^{\wedge} 3 /$ day & $\begin{array}{l}\text { Net } \\
\text { Balance } \\
\mathrm{m}^{\wedge} 3 / \text { day }\end{array}$ \\
\hline \multicolumn{5}{|c|}{123 days } \\
\hline Zone 2 to 1 & 983560 & Zone 1 to 2 & 961830 & 21730 \\
\hline Zone 3 to 1 & 511150 & Zone 1 to 3 & 374060 & 137090 \\
\hline Zone 4 to 1 & 0 & Zone 1 to 4 & 174.17 & \\
\hline \multicolumn{5}{|c|}{ 246davs } \\
\hline Zone 2 to 1 & 874530 & Zone 1 to 2 & 859780 & 14750 \\
\hline Zone 3 to 1 & 429330 & Zone 1 to 3 & 359450 & 69880 \\
\hline Zone 4 to 1 & 0 & Zone 1 to 4 & 119.32 & -119.32 \\
\hline \multicolumn{5}{|c|}{ 365davs } \\
\hline Zone 2 to 1 & 766610 & Zone 1 to 2 & 748630 & 17980 \\
\hline
\end{tabular}

\begin{tabular}{|l|r|l|l|l|}
\hline Zone 3 to 1 & 385030 & Zone 1 to 3 & 359450 & 25580 \\
\hline Zone 4 to 1 & 0 & Zone 1 to 4 & 114.8 & -114.8 \\
\hline $\begin{array}{l}\text { Zone 1= Unconfined aquifer, Zone2 = First confined } \\
\text { aquifer } \\
\text { Zone3= Second confined aquifer, Zone 4= Third confined } \\
\text { aquifer }\end{array}$
\end{tabular}
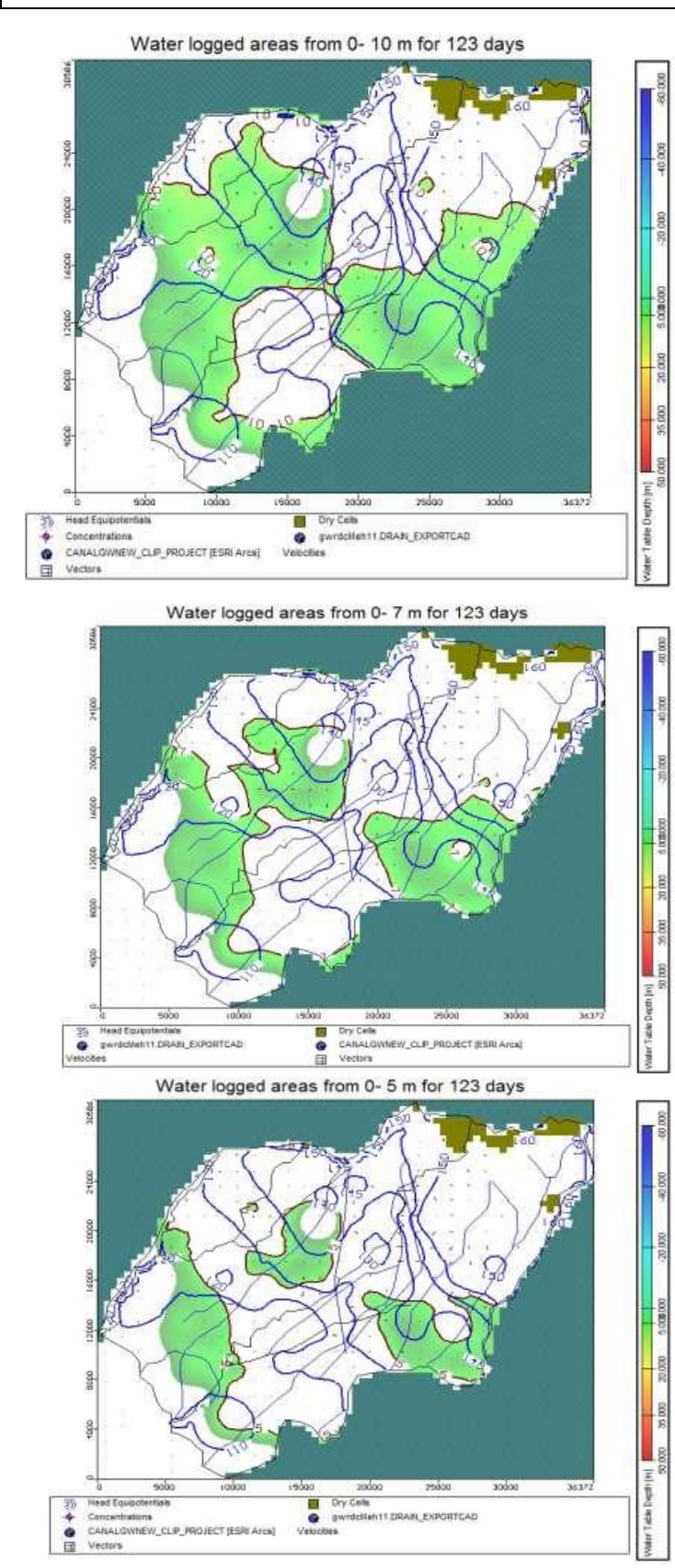

Figure 15 Water logging Area in different Time Period

The water logged area is considered for different water levels 0 to $10 \mathrm{~m}, 0$ to $7 \mathrm{~m}$ and 0 to $5 \mathrm{~m}$ mainly during Kharif (123 days). Accordingly the dewatering efforts can be made .The water logged area from 0 to $10 \mathrm{~m}$ during Kharif season (123 days) is given below.

The water logged area from 0 to $5 \mathrm{~m}$ during Kharif season (123 days) is given above. The area of the water logged area is about 127 sq.km. 
The recharge capabilities in the area has been estimated based on the head difference and the aquifer parameters. The same is shown below for $5 \mathrm{~m}$ dewatering in the area both for first confined and second confined aquifers. This has been calculated using the Conductivity values estimated from the pumping test data and the radius of influence of about $500 \mathrm{~m}$ for first confined and $1000 \mathrm{~m}$ for the second confined aquifers. The rise of water level due to the recharge has been estimated considering the specific yield values of 0.015 for first confined and 0.006 for the second confined aquifers.

\section{Table 4 Calculations}

\begin{tabular}{|l|r|r|}
\hline $\begin{array}{l}\text { Basic information of Recharge tube wells - Average } \\
\text { Conditions }\end{array}$ & 32 \\
\hline $\begin{array}{l}\text { Average thickness of Ist aquifer(m)- } \\
\text { Unconfined }\end{array}$ & 32 & 40 \\
\hline Average thickness of 1st confining clay- m & 8 & 53 \\
\hline $\begin{array}{l}\text { Average thickness of IInd aquifer (m)- } \\
\text { cinfined first aquifer }\end{array}$ & 13 & 59.5 \\
\hline Average thickness of 2nd confining clay & 6.5 & 74.5 \\
\hline $\begin{array}{l}\text { Average thickness of 3rd aquifer (m)- 2nd } \\
\text { Cinfined aquifer }\end{array}$ & 15 & 0.5 \\
\hline Average water level in monsoon(m-bgl) & 0.5 \\
\hline
\end{tabular}

\begin{tabular}{|l|c|c|}
\hline \multicolumn{3}{|c|}{ Expected Recharge due to construction of Recharge wells in the } \\
\hline Details & $\begin{array}{l}\text { Recharge } \\
\text { to } \\
\text { first } \\
\text { confine } \\
8.14\end{array}$ & $\begin{array}{l}\text { Recharge } \\
\text { to second } \\
\text { confined }\end{array}$ \\
\hline Permeability(k)= m/day & 0.1 & 0.1 \\
\hline Radius of well(rw)-m & 250 & 600 \\
\hline Radius of Influence(r0)-m & 48 & 69 \\
\hline $\begin{array}{l}\text { ho( head above the bottom of the aquifer } \\
\text { when no pumping is taking - average (m) }\end{array}$ & 50.25 & 71.5 \\
\hline $\begin{array}{l}\text { hw (head above the bottom of the aquifer } \\
\text { while recharging - average (m) }\end{array}$ & 13 & 15 \\
\hline Thickness(b)-m & 191.4 & 268.5 \\
\hline Discharge of well(q)-m3/day & 2.22 & 3.11 \\
\hline Discharge of well (q)- lps & 250 & 600 \\
\hline Radius of influence of each well(r0- (m) & 196250 & 1130400 \\
\hline Area of each well (sq.m) 3.14*r^2 & 5.10 & 0.88 \\
\hline no of wells per sq.km & 1023.85 & \\
\hline Reacharge per sq.km per day (cum) & 73717.36 & 17100.40 \\
\hline $\begin{array}{l}\text { Reacharge per sq.km in monsoon (72 } \\
\text { days)-cum }\end{array}$ & 51192.61 & 11875.28 \\
\hline $\begin{array}{l}\text { Recharge due to canal of 99 days of Rabi } \\
\text { (50 \%) }\end{array}$ & 124909.97 & 28975.69 \\
\hline Total Recharge per year per sq.km-cum & 0.125 & 0.029 \\
\hline Total Recharge per year per sq.km-mcm & 127 & 127 \\
\hline $\begin{array}{l}\text { Total Recharge area upto 5 m below } \\
\text { Ground level ( sq.km) }\end{array}$ & 647 & 112 \\
\hline Total expected recharge (mcm) & & 3.68 \\
\hline $\begin{array}{l}\text { Total No of Recharge wells that can be } \\
\text { constructed in the 127 sq.km area }\end{array}$ & & \\
\hline
\end{tabular}

\begin{tabular}{|l|l|l|}
\hline $\begin{array}{l}\text { Expected rise of water level }(\mathrm{m}) \text { with Sy of } \\
0.015 \text { for first confined and } 0.006 \text { for second } \\
\text { confined during rainy season } 4.91\end{array}$ & 2.85 & \\
\hline $\begin{array}{l}\text { Expected rise of water level (m) with } \\
\text { Sy of } 0.015 \text { for unconfined and } 0.006\end{array}$ & 1.98 & \\
for confined during canal operation) & & \\
3.41 & & \\
\hline
\end{tabular}

This indicates that about 647 wells can be constructed for artificial recharge in the area with an average of 5 well per sq. $\mathrm{km}$ and about $15.86 \mathrm{mcm} /$ year for first confined and about $3.68 \mathrm{mcm}$ for the second confined aquifer can be recharged in a year. This will result in about 4.91 rise in first confined aquifer and about $2.85 \mathrm{~m}$ rise in the second confined aquifer due to monsoon and about $3.41 \mathrm{~m}$ in first confined aquifer and about $1.98 \mathrm{~m}$ in the second confined aquifer due to canal recharge.

\section{ACKNOWLEDGEMENTS}

Authors like to thank Ground Water Resource Development Corporation LTD, Government of Gujarat for the financial assistance to carry out this project. This paper is an outcome of the study results.

\section{REFERENCES}

Sharma and Gupta (1987) have studied the flow of groundwater through different aquifers in Mehsana by tritium study.

Bradley and Phadtare (1989) has studied the aquifers of Mehsana in detail.

Rushton and Tiwari, (1989) have studied the Regional studies of the Mehsana alluvial aquifer regarding the vertical flows and arrived at the conclusion that the vertical flow through clay zones are the ultimate source of most of the water that is pumped from the tube wells and that the horizontal flows account for about $5 \%$ of the abstraction.

Rushton (1990)has reviewed the Methods of estimating the quantity of water leaving the soil zone towards the deeper aquifer in the Mehsana aquifer.

M.V.Patel (1992) has developed a mathematical model for determination of aquifer parameters in alluvial areas with special reference to Rupen Basin, Mehsana.

Columbia Water Centre 2011has conducted surveys to confirm that the groundwater crisis in North Gujarat is severe and likely to get worse.

Majumdar, P. K., Sekhar, M., Sridharan K., Mishra, G. C.(2008)has conducted Numerical simulation of groundwater flow with gradually increasing heterogeneity due to clogging.

N. B. KAVALANEKARA, S. C. SHARMA and K. R. RUSHTON, Dec 2009 have studied the over exploitation of groundwater resources in Mehsana.

P.K.Majumdar(2008) has also modelled the water logging conditions of parts of Rupen basin.

S.D.DhimanandA.K.Kesarihave (2002) studied groundwater modelling for Mehsana aquifers. 